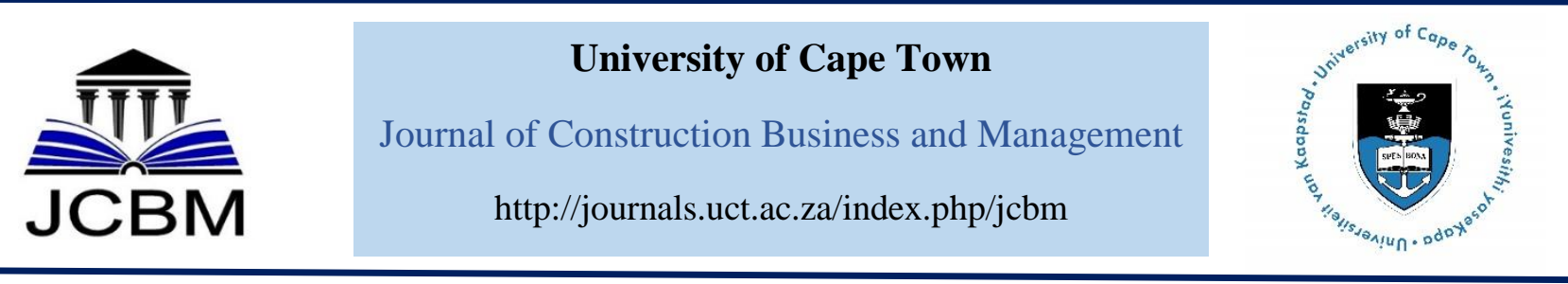

\title{
Examination of the Levels of Development of Building Information Models in the Nigerian Construction Industry
}

\author{
O. Olugboyega ${ }^{1}$, and O. O. Aina ${ }^{2}$ \\ ${ }^{1.2}$ Department of Building, Obafemi Awolowo University, Ile-Ife, Nigeria
}

Received 21 June 2017; received in revised form 25 August 2017, 18 July 2018; accepted 20 July 2018 https://doi.org/10.15641/jcbm.2.2.2018.99

\begin{abstract}
BIM can be used to illustrate the entire building lifecycle, from cradle to inception, design and demolition and materials reuse; quantities and properties of materials, which can be easily extracted from the model; and the scope of works, including management of project targets and facilities management throughout the building's life. The implementation of BIM in projects or organization is in phases and building information models can be developed as 2D, 3D, 4D, 5D and 6D BIM depending on the stage of BIM implementation and level of details required. This study examined the levels of details of building information models being generated by two hundred and eighty two construction professionals in Lagos State, Nigeria using respondents driven sampling technique. Frequency distribution and percentage, clustered bar chart, mean ranking, Kruskal Wallis test and Fisher exact test were used to analyse the data obtained from the respondents. The study found that the implementation of BIM in the study area is for visualization purpose. The findings also revealed that the levels of generating 2D and 3D BIM were very high in the study area; and that 3D architectural model, 3D architectural and structural model, and 3D architectural and building services model were the most developed variants of 3D BIM. It was concluded that that the status of BIM adoption in construction industry in Lagos State, Nigeria is at the visualization phase. Keywords: BIM details, BIM, BIM development, 4D BIM, federated BIM.
\end{abstract}

\section{Introduction}

Building information modelling (BIM) is an accurate parametric and 3D geometrical representation of a building or any structure digitally (Bhargav, 2014). In BIM, the three-dimensional (3D) model of a building can be combined with change management information to give a four-dimensional (4D), five-dimensional (5D) or six-dimensional (6D) model of the building. Sebastian (2010) and Simpson (2013) describe this practice as a process that gives meaning to the building information models through relationships. BIM is regarded as the future and the solution to the construction industry's problems (Lu and Li, 2011).

BIM as a process, is significantly altering the way that the construction industry creates and cares for its assets; mostly because it allows the identification and reduction of errors and design conflicts before they actually happen as well as reduces process waste by eliminating rework (Scott, Chong and Li, 2005). The body of knowledge has shown the extent of implementation and levels of development of building information models among construction professionals in the developed countries, for example, Australian Institute of Architects (2014), BIMforum (2015), UKBIM alliance (2016), and UK National BIM Report (2017). In Nigeria, a number of studies have recently been done on BIM. Ede (2014) reported a case study of usage of BIM on a modest duplex building project in Enugu. Although, the study did not report the level of details of BIM used for the project, but it reinforces the need to investigate other BIM-based projects that have not been reported. Dare-Abel, Igwe and Charles (2014) studied the usage of software technologies by architectural firms in Abuja, Enugu, Maiduguri,

\footnotetext{
${ }^{1}$ Corresponding Author. Tel: +2348066704465

Email address: oolugboyega@yahoo.com
} 
Kaduna and Lagos. The usage of software technologies among construction professionals is bound to vary and a study focused on only the architects cannot be said to have evaluated the usage of software technologies among the construction professionals.

Besides, knowledge on the building information models being generated from the software technologies is more important than the software technologies that they are using. A desktop study of the change process associated with BIM implementation on projects as carried out by Dim, Ezeabasili and Okoro (2015) reviewed literature on how the use of BIM for projects will impact the design and construction process. In whatever way, these studies did not provide adequate insight on the level of development of building information models. The examination of the extent of BIM-enabled collaboration improvement among AEC consultants in Nigeria, as conducted by Onungwa and Uduma-Olugu (2017) did not consider the importance of contents of the federated building information models being generated by these consultants. The consideration of this would have provided information on the extent of collaboration and the details of the building information models being exchanged and integrated. Collaboration among consultants is not a stand-alone issue; it is affected by the numbers of the consultants and the knowledge they are contributing. Therefore, examining collaboration practices among the consultants is an unrepresentative way of examining the adoption of BIM in a construction industry. Sawhney (2014) affirmed that the usage of BIM must be evaluated in order to provide the construction industry with timely and clear understanding of the status of BIM adoption in comparison with global developments. As noted by Jung and Lee (2015), a study on the usage of BIM should examine its level of implementation and details. Moreover, the existing literature on the level of development of building information models globally cannot be said to have captured the level of development of building information models in Nigeria; as the conditions in the Nigerian construction industry are different due to geographic location, size and complexity of projects, and contractual arrangements.

Smith (2013) maintained that BIM can be used to transform the construction industry into an efficient and value-oriented sector that can successfully deliver the clients' requirements, and that, BIM can transform the construction industry to a data-rich environment and knowledge-intensive industry which can enable virtual and automated design, analysis, construction and communication. However, these are untested assumptions. For a gainful deployment of BIM in Nigeria, It is therefore important to study the levels of development of building information models by construction professionals in Nigeria. In order to understand the status of BIM adoption in Nigeria, this study examined the phase of BIM implementation and extent of generating building information models by construction professionals in the construction industry in Lagos State, Nigeria.

\section{Literature Review}

BIM is the process of developing an intelligent building model which can be more easily modified, and which can accurately represent the final building product (Computer Integrated Construction Research Group [CICRP], 2012). In BIM, virtual designs are built in $3 \mathrm{D}$ before work proceeds on site; the attributes of all the elements of the building can be found in the model; and spatial 'clashes' can be identified and resolved in the model instead of on site (CPA, 2013). As observed by RIBA (2012) and Sebastian (2010), BIM is more than 3D, it could be 4D when time or work schedule information is added to the project model or $5 \mathrm{D}$ when cost or quantity schedule information is given in the model or 6D when facilities management information is added to the model. BIM provides an integrated system that can be used to simulate the behaviour of buildings in a real-world system, provides information about quantities and properties of building elements, and documents design information in an integrated database (Sabol (2008), Ian and Bob (2010) and Royal Institute of British Architects [RIBA], 2012). Additionally, BIM can be used to illustrate the entire building lifecycle, from cradle to inception, design and demolition and materials reuse; quantities and properties of materials, which can be easily extracted from the model; and the scope of works, including management of project targets and facilities management throughout the building's life (NBSBR, 2014). As noted by Shelden (2009), BIM is the most promising recent development in the construction industry and an important tool for the growth of the construction industry. Similarly, Newton and Chileshe (2012) affirmed that BIM is imperative to the efficiency and competitiveness of the construction industry. Succar (2009) argued that BIM can stimulate the process of information exchange and interoperability among project stakeholders. This supports the view of Panuwatwanich, Wong, Doh, Stewart and McCarthy (2013) that the need for BIM stems from the lack of integration along the construction supply chain. Also, BIM Guide (2013) asserted that BIM would change the traditional process of working in the construction industry over a wide range of its typical characteristics, including those of people, processes, communication and work culture.

The level of development of building information models can be classified as 2D, 3D, 4D, 5D and 6D BIM depending on the level of details required and on the ability of the construction supply chain to operate and exchange information (Engineering News Record, 2014; Sawhney, 2014; Smith, 2014). The level of development of building information models is used to define the level of information required for modelling and maturity of the necessary IT technology, supporting infrastructure, collaboration and integration required at each level of capacity and is expected to be used by the BIM project strategy team to prioritise development of the BIM infrastructure (RIBA, 2012; Practical BIM, 2012; BIM Guide, 2013; Bolpagni, 2013; Eadie et al., 2014; British Standard Institute [BSI], 2013; Porwal and Hewage, 2013; BIM Planning Guide for Facilities Managers, 2012).

A 2D BIM is a conventional building model created using computer aided design (CAD) software technologies where building geometry is represented by 
lines between defined points. 2D based modelling evolved from pencils to ink, to overlay drafting, and to CAD technologies. It does not provide visualization, thinking and documentation, but leaves building information to imaginations (Arcadis, 2015). 2D BIM is the starting point for BIM implementation and it involves the use of CAD software with 2D files to design and produce only traditional drawings. In 2D BIM, information is often sent as Portable Document Format (PDF) and files are printed off on paper (RIBA, 2012; BIM Guide, 2013; Smith, 2014). According to Eadie et al. (2014), Oakley (2014) and BSI (2013), 2D BIM is document oriented and involves drawings in 2D CAD software technologies, calculation in Excel and processing of information using Microsoft word. The information from 2D BIM can be described as 'non-intelligent' information as no digital objects are utilized and professionals only employ texts, lines and arcs to prepare and communicate data. However, the information models created by project participants at 2D BIM require coordination in order to detect and correct information clash (Building Information Council, 2014). CAD software technologies employed in 2D BIM merely automated the process of drawing, design and documenting building information; but cannot represent the relationships between building elements; for example, the architectural information model is represented by 2D geometry of a building via graphical elements such as lines, arcs and symbols (Autodesk, 2002; Ian and Bob, 2010).

3D BIM is an object oriented models of buildings where virtual abstract representations of real life known as objects are used to represent components such as doors, windows or columns. Unlike 2D BIM that uses a collection of lines to represent building components on a drawing, 3D BIM gives a model consisting of virtual objects with a homogeneous geometrical description. It brings an immediate and understandable representation of the available design of a building and makes it easier to make changes in the design (Engineering News Record, 2014). Where only the information about the geometry of a building is required, the model can be developed as a 3D model, and this type of federated building information models is known as 3D BIM with visualization as the level of detail. Examples of software technologies that can be used in generating 2D or 3D BIM are MS Project, MS Outlook, Orion, ROBOT, Magi CAD, AutoCAD Architecture, AutoCAD MEP, Autodesk REVIT, Graphisoft ArchiCAD and Bentley Architecture (Royal Architectural Institute of Canada [RAIC], 2007; CICRP, 2011). 2D or 3D objects in 3D BIM usually have geometric description to which intelligence can be linked to create a federated building information model. The coordination of disciple-specific information models is also required for $3 \mathrm{D}$ BIM in order to avoid error and defective works (Eadie et al., 2014; BSI, 2013; Oakley, 2014).

The increased usage of both 2D and 3D CAD software technologies has been reported in a number of studies (Smith, 2014; BIM Guide, 2013; Ian and Bob, 2010; Building Information Council, 2014; and RIBA, 2012). For example, Building Information Council (2014) reported that $3 \mathrm{D}$ BIM primarily gives visualizations, concepts of designs and plans of project team members by creating geometry of buildings in support of visualization, realistic rendering and lighting effects. In 3D BIM only one party, usually the architects and engineers, develop a $3 \mathrm{D}$ information model for the project and other project team members only employing CAD software technology to develop building information without necessarily collaborating with one another. A level of collaboration could be done though to provide a common data environment for the project team by exchanging information models on compatible BIM software platforms. Other dimensions can be added to a 3D BIM by way of increasing the database with other information, and where time is added as the fourth dimension, the model is known as 4D BIM, 5D BIM when cost analysis and management information are added and when maintenance information is added, the model becomes a 6D BIM. Although, other dimensions can be added to $\mathrm{BIM}$ to generate ' $\mathrm{nD}$ BIM' depending on the project requirements; but the major benefit of BIM is achieved at 6D BIM (also known as integrated BIM [iBIM]) because it supports collaborative use of project information, provides a single or master model and provides greater use for the information in the model (Sabol, 2008; RAIC, 2007).

The level of details in BIM is very important to understand the construction process because elements in a 3D BIM model have to be in accordance with the schedule. The fourth dimension is an extra feature that provides the model with more dynamism in terms of representing the behaviour of the building elements along time, extending in this way its usage for other purposes. A 4D BIM takes the level of details in a BIM to another dimension by simulating the construction process of the 3D models using construction planning software technology. 4D BIM enables the team to introduce the construction sequence into the model, simulating the process, checking for mistakes and looking for optimizations. It increases the quality of the design and the cost effectiveness of construction and construction logistics (Velasco, 2013). Examples of software technologies that can be used to generate $4 \mathrm{D}, 5 \mathrm{D}$ or $6 \mathrm{D}$ BIM are Navisworks, Tekla structures, Bentley Navigator, Dinamo, DAYSIM among others (BIM Handbook, 2011; Velasco, 2013).

Conversely, VicoSoftware (2015) argued that 2D BIM still remains the cornerstone of construction contracts as 2D vector-based software technologies are still required to produce and document contract information and that $3 \mathrm{D}$ BIM is a collection of objects such as walls, slabs, columns, doors, and windows. In 5D BIM, 'quantification' is required only to integrate quantity takeoff, location-based quantities, resources, productivity rates, and labour costs information into the 3D model and time dimension. As an estimating dimension, it gives the cost of the item, the cost of the crew to install it, the tools and materials necessary to install it, and its quantities per location (Arcadis, 2015). The sixth dimension in the level of BIM details is the operation and maintenance or sustainability information. This level analyses the models for maintenance or sustainability criteria (Velasco, 2013). VicoSoftware (2015) noted that 6D BIM is impossible to develop without interoperability and data exchange standards. 
The classification for the level of development of building information models was mainly based on geometrical information and other dimensions of building information such as cost, time, maintenance, and sustainability. This classification is not apt for developing construction industries, for example, the Nigerian construction industry, where there exists no framework for the level of development of building information models for varied sizes of projects, types of clients, and diverse project delivery systems. For BIM implementation rationale in the developing construction industries, the numerals of building information models in a federated building information model could be used to classify the level of development of building information models, regardless of the geometry and dimensions of the constituent building information models in the federated building information models. This will trim down the level of intricacies, cost and information required in the development of building information models. This will in no way diminish the benefits to be derived from BIM process, but will bring down the cost of BIM process, and make BIM adaption easier in small projects, small firms, and developing construction industries.

\section{Method}

Primary data required for the study was obtained through the administration of structured questionnaire. The study population composed of construction professionals who have substantial involvement and responsibilities in BIM and who have generated building information models at any level of details for projects in Lagos State. These included the Architects, Quantity Surveyors, Facilities Managers, Civil and Structural Engineers, Building Services Engineers (Mechanical and Electrical) and Builders. At present, the comprehensive lists of these professionals are not available and this justified the adoption of purposive sampling for selection of the respondents for the study. Purposive sampling was adopted for the study. The selection of respondents for the study was done using Respondent Driven Sampling (RDS) technique. RDS is a sampling technique based on the principle of 'six degrees of separation', with the potential to reach any member of a population in six waves and involves a network-based methods that start with a set of initial respondents (driver respondents) who refer their peers; these in turn refer their peers up to the sixth wave.

A list of construction professionals who had generated building information models at any level of details in project was compiled using contacts list from social media based on the recommendation of Kossinets and Watts (2006). The construction professionals were divided into professional groups and the contacts list for each professional group was taken as the Personal Network Size (PNS) for the group. PNS for this study is the number of known professionals who had generated building information models at any level of details and it is required to determine the target population. The PNS for each of the professional group is as shown in Table 1.

Table 1: PNS and RDS Respondents Estimate and Target Population

\begin{tabular}{lccc}
\hline Professional group & $\begin{array}{c}\text { Personal Network Size } \\
\text { (PNS) }\end{array}$ & $\begin{array}{c}\text { Estimated number of } \\
\text { respondents }\end{array}$ & $\begin{array}{c}\text { Minimum Target Sample } \\
\text { Size (MTSS) }\end{array}$ \\
\hline Architects & 16 & 96 & 77 \\
Builders & 11 & 66 & 57 \\
Building services engineers & 9 & 54 & 48 \\
Facilities managers & 4 & 24 & 23 \\
Quantity surveyors & 4 & 24 & 23 \\
Structural/Civil engineers & 8 & 48 & 43 \\
\hline Total MTSS for the study & & $\mathbf{2 8 2}$ & \\
\hline
\end{tabular}

The RDS target population required for the study depends on RDS respondents estimate and this was determined by calculating the degree of person (di) and degree of distribution (Pdij) for the PNS using the summation method proposed by McCarthy et al., (2001). The RDS respondents estimate is presented in Table 1 . The potentials of the PNS to name other respondents in six waves were summed to yield an overall estimate. The degree of person (di) was calculated using the formula given by McCarty et al. (2001).

$$
d i=\sum P d i j \quad \text { (Equation 1) }
$$

Where:

$d i=$ the degree of person $i$;

Pdij = 1 (if person $i$ knows person j); and

$\sum P d i j=6$ (for six degrees of separation).

RDS target population was then determined by calculating the minimum target sample size (MTSS) for each of the professional group using the formula given by Glen (2013).

$n=\frac{N}{1+N(e)^{2}}$

(Equation 2)

Where:

$n=$ sample size;

$N=$ population size; and

$e=$ level of precision .

RDS target population for the study is as presented in Table 1. MTSS is required to compensate for differences in homophily and PNS across group and also to determine when the RDS should be stopped. The RDS for this study was stopped when the MTSS for each professional group was reached. Information obtained from the respondents included the levels of details and phase of implementation of BIM. Frequency distribution and percentage, clustered bar chart, mean ranking, Kruskal Wallis test and Fisher 
exact test were used to analyse the levels of BIM in use and degree to which the professional groups vary in their level of BIM usage. Where the ratings of the professional groups for a question were formed into contingency tables, Fisher exact test was used to determine if there were significant differences in the ratings indicated by the professional groups. The hyper-geometric probability function to determine significance value in Fisher exact test was calculated using the following formula as given by Weisstein (1999):

$P=\frac{\left(R_{1} ! R_{2} ! \ldots \ldots R_{m} !\right)\left(C_{1} ! C_{2} ! \ldots \ldots C_{n} !\right)}{N ! \prod_{i j} a i j !}$

(Equation3)

Where:

$N=$ total number of values in all the groups $=\sum i R i=\sum j C j$

$R i=$ row sums

$C i=$ column sums

aij $=$ number of observations in which $x=i$ and $y=j$

To determine if the ratings for a set of questions on the objective originated from the same professional group and to show if there are statistically significant differences among construction professional groups, Kruskal Wallis test was conducted on the responses owing to its sensitivity to unequal means. The discrepancies among the rank sums were combined to create a single value called Kruskal Wallis statistic using the formula given by National Institute of Standards and Technology (2015):

$$
H=\frac{12}{n(n+1)} \sum_{i=1}^{k} \frac{R_{i}^{2}}{n i}-3(n+1) \quad \text { (Equation4) }
$$

Where

$n i=$ sample sizes for each of the $k$ groups

$R i=$ sum of the ranks for group $i$

\section{Results}

\subsection{Profile of respondents}

The total MTSS of two hundred and eighty two construction professionals (282) as determined from the RDS target population guided the total number of respondents surveyed for the study. Seventy-eight responses were from Architects, representing 27.7\% of the total respondents. Fifty-nine responses were from Builders (20.9\%), fifty-one from Building Services Engineers (18.10\%), forty-six from Structural Engineers (16.3\%), twenty-four from Quantity Surveyors (8.5\%) and twenty-four from Facilities Managers (8.5\%). This shows that all the construction professional groups were represented in the survey and the conclusions from this study won't be biased.

Regarding the academic qualification of the respondents, $38.3 \%$ of respondents were BSc. holders, followed by respondents holding M.Sc. Degree accounting for $34.0 \%$ of the total respondents. Respondents who were HND holders accounted for
$27.0 \%$ of the respondents; while respondents who were $\mathrm{PhD}$ holders accounted for $0.7 \%$ of the total respondents. This suggests that the respondents are well educated and would be able to respond to the questions with understanding. The distribution of respondents according to number of projects they had been involved in was also surveyed. Respondents who had been involved in at least 16 projects accounted for $26.2 \%$ of the total respondents, followed by respondents who had been involved in at least 11 projects, representing $25.5 \%$ of the total respondents. $20.6 \%$ of respondents have been involved in at least 5 projects, while $12.8 \%$ of respondents have been involved in more than 21 projects. This shows that the average respondents had participated in about seven projects. This shows that the respondents have enough working experience to provide the required information for this study.

On the subject of the experience level of the respondents for this study. Only $50.4 \%$ of the surveyed respondents had at least 5 years of experience in the Nigerian construction industry. $32.6 \%$ of the total respondents are professionals with at least 11 years of working experience. No more than $8.5 \%$ participants have less than 5 years' experience. While $2.1 \%$ of the total respondents have worked in the construction industry for 21 years and above. This suggests that there was great depth in the experience possessed by the respondents and that the information provided by these professionals can be considered reliable.

\subsection{Phase of BIM implementation adopted for work processes in the study area}

To achieve the objective of this study, it was noted that implementation of BIM in projects or organizations is in phases; and that BIM could be developed as 2D building information model (2D BIM) and federated building information models (3D, 4D, 5D and 6D BIM) depending on the stage of BIM implementation and level of details required for the project or applicable in the organization. Respondents were therefore asked to identify the phases of BIM implementation that they had adopted for their work processes.

The phases of BIM implementation employed by the respondents were analysed using frequency distribution and percentage and clustered bar chart, this is as presented in Figure 1. A significant number of respondents $(19.9 \%$ and $18.4 \%$ ) were still at visualization phase of BIM implementation and visualization with coordination phase of BIM implementation respectively, as shown in Figure 1. Only $11.3 \%$ of the respondents indicated that they were sharing digital information among project team members. However, BIM models were still not being shared collaboratively among project team members, as only $4.3 \%$ of the total respondents indicated that they shared information models collaboratively. While, $12.8 \%$ of the total respondents indicated that they were adjusting the work process towards BIM process. 


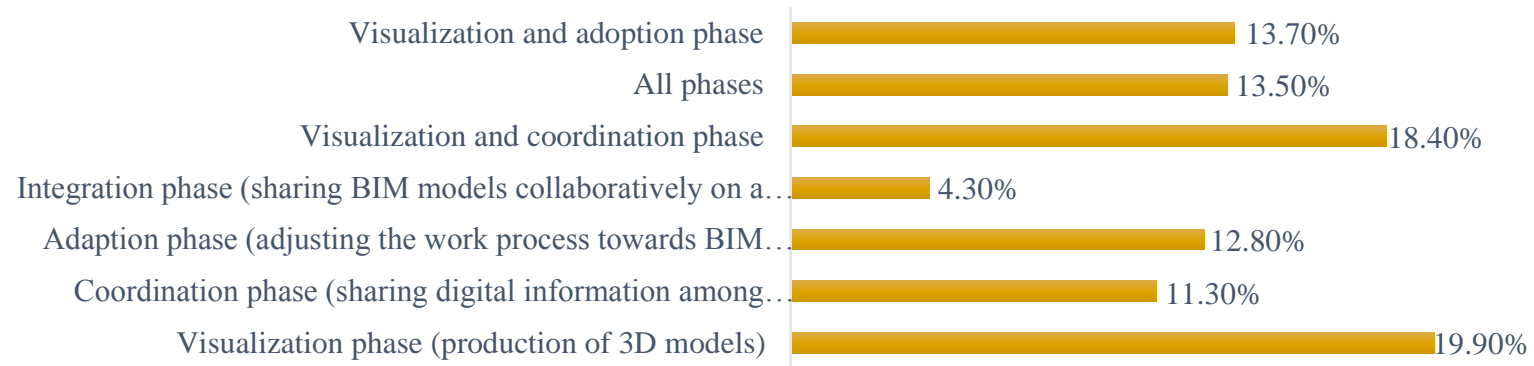

- Phase of BIM implementation among construction professionals

Figure 1: phase of BIM implementation among the surveyed construction professionals.

\subsection{Generation of 2D BIM in the study area}

Professionals had adopted Computer Aided design (CAD) and were using it in so many forms, such as $2 \mathrm{D}$ and 3D CAD. CAD adoption is often described as the starting point for BIM adoption. Therefore, the study examined the level of generating 2D BIM among the construction professionals. A 5-point Likert scale was adopted for the study, where 1 = very low level of generation, $2=$ low level of generation, $3=$ average level of generation, $4=$ high level of generation, and 5= very high level of generation. It can be seen from Figure 2 that, $34 \%$ of the respondents indicated high usage of 2D BIM for projects, $31.9 \%$ indicated very high level of generation of 2D BIM; while $9.9 \%$ indicated average level of generation of 2D BIM. No more than $4.3 \%$ and $19.9 \%$ of the total respondents indicated very low level of generation of 2D BIM and low level of generation of 2D BIM respectively.

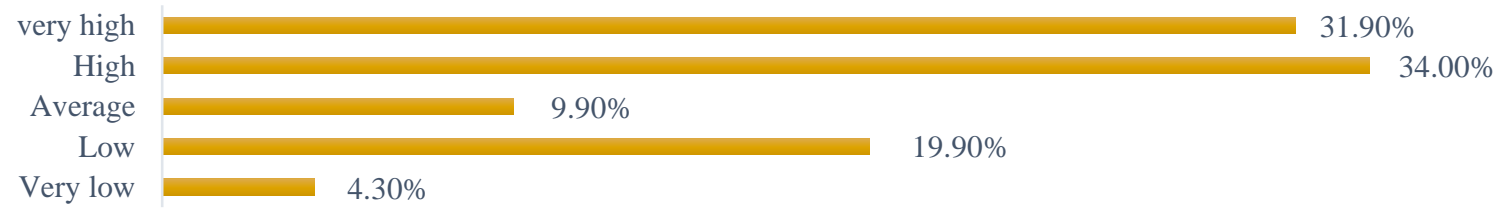

Adoption level of 2D BIM

Figure 2: Level of generating 2D BIM among Construction Professionals.

A test of significance difference and ranking of the level of generation of 2D BIM among construction professionals was conducted using Kruskal Wallis test and mean score. As shown in Table 2, the variance in the level of 2D BIM being generated among construction professionals is significant. Builders accounted for the majority of those with high level of generation of 2D BIM with a mean score of 4.27. Facilities managers and quantity surveyors also have high level of generation of 2D BIM with a mean score of 4.00; while architects and structural/civil engineers have average level of generation of 2D BIM with mean scores of 3.97 and 3.08 respectively. Only building services engineers recorded low level of generation of 2D BIM with a mean score of 2.08 .

Table 2: Mean score and Kruskal Wallis Test on Levels of generating 2D BIM among Construction Professionals.

\begin{tabular}{|c|c|c|c|c|c|c|c|c|c|}
\hline Construction Professionals & $\begin{array}{l}\text { Very } \\
\text { Low }\end{array}$ & Low & Average & High & $\begin{array}{l}\text { Very } \\
\text { High }\end{array}$ & Total & $\begin{array}{l}\text { Mean } \\
\text { Score }\end{array}$ & Rank & $\begin{array}{c}\text { Significant } \\
\text { value }\end{array}$ \\
\hline Architect & 0 & 0 & 28 & 24 & 26 & 78 & 3.97 & 4 & \multirow{6}{*}{0.001} \\
\hline Builder & 0 & 7 & 0 & 22 & 30 & 59 & 4.27 & 1 & \\
\hline Building service Engineers & 0 & 49 & 0 & 2 & 0 & 51 & 2.08 & 6 & \\
\hline Facilities Manager & 0 & 0 & 0 & 24 & 0 & 24 & 4.00 & 2 & \\
\hline Quantity surveyor & 0 & 0 & 0 & 24 & 0 & 24 & 4.00 & 2 & \\
\hline Structural/Civil Engineer & 12 & 0 & 0 & 0 & 34 & 46 & 3.08 & 5 & \\
\hline Total & \multicolumn{8}{|c|}{282} & \\
\hline
\end{tabular}

\subsection{Forms of 3D BIM being generated in the study area} In order to obtain information on the level of details of 3D BIM in use among the surveyed construction professionals, 3D BIM dimensions were broken up into different variants by describing them according to possible numerals of the building information model contained in the federated building information models.
Respondents were then asked to indicate the rate of generating 3D BIM dimensions and their variants. The standard form of 3D BIM is 3D architectural and engineering (structural and building services) models. However, most professionals develop 3D BIM in some other form than the standard 3D BIM. Table 3 shows the forms of 3D BIM being generated by the surveyed 
construction professionals, together with the level of generating standard 3D BIM. Forms of 3D BIM with high level of development by the surveyed construction professionals were 3D architectural model, 3D architectural and structural model and 3D architectural, electrical and mechanical model. Standard 3D BIM (architectural, structural, electrical and mechanical models), 3D structural model and 3D structural, electrical and mechanical model were rated as having low level of generation.

Table 3: Level of generating 3D BIM and its variants by construction professionals

\begin{tabular}{|c|c|c|c|c|c|c|}
\hline 3D BIM and its variants & $\begin{array}{l}\text { Very } \\
\text { Low } \\
\end{array}$ & Low & Average & High & $\begin{array}{l}\text { Very } \\
\text { high }\end{array}$ & $\begin{array}{l}\text { Mean } \\
\text { Score }\end{array}$ \\
\hline $\begin{array}{l}\text { Standard 3D BIM (architectural, structural, } \\
\text { electrical and mechanical models) }\end{array}$ & $24.80 \%$ & $21.30 \%$ & $18.40 \%$ & $15.60 \%$ & $19.90 \%$ & 2.84 \\
\hline 3D architectural model & $24.80 \%$ & $0.00 \%$ & $6.70 \%$ & $28.70 \%$ & $39.70 \%$ & 3.59 \\
\hline 3D architectural and structural model & $24.10 \%$ & $0.00 \%$ & $13.50 \%$ & $48.90 \%$ & $13.50 \%$ & 3.28 \\
\hline 3D structural model & $29.80 \%$ & $21.30 \%$ & $4.30 \%$ & $24.80 \%$ & $15.60 \%$ & 2.62 \\
\hline 3D structural, electrical and mechanical model & $46.10 \%$ & $16.30 \%$ & $18.40 \%$ & $9.90 \%$ & $9.20 \%$ & 2.20 \\
\hline 3D architectural, electrical and mechanical model & $29.80 \%$ & $0.00 \%$ & $18.10 \%$ & $27.30 \%$ & $24.80 \%$ & 3.17 \\
\hline
\end{tabular}

\subsection{Forms of 4D BIM being generated in the study area} Standard 4D BIM can be generated by adding time dimension to standard 3D BIM. Therefore, this study examined the level of generating 4D BIM by construction professionals in the study area. Different forms of 4D BIM were identified and presented to the respondents. As explained in Table 4, 36.9\% of the respondents were adding time dimension to 3D architectural model to generate a form of 4D BIM. Similarly, for the standard 4D BIM, $14.9 \%$ of the total respondents indicated high level of generation; while $33.3 \%$ indicated low level. Among the variants of 4D BIM, only 3D architectural model and time dimension had average level of generation with a mean score of 3.11; while Standard 4D BIM (standard 3D BIM and time dimension), 3D structural model and time dimension, 3D architectural model and cost dimension, 3D architectural and structural model and cost dimension and 3D architectural and structural model and facilities management had low level of generation with an average mean score of 2.34 .

Table 4: Level of generating 4D BIM and its variants among construction professionals

\begin{tabular}{|c|c|c|c|c|c|c|}
\hline 4D BIM and variants & $\begin{array}{l}\text { Very } \\
\text { low }\end{array}$ & Low & Average & High & $\begin{array}{l}\text { Very } \\
\text { high }\end{array}$ & $\begin{array}{l}\text { Mean } \\
\text { Score }\end{array}$ \\
\hline 3D architectural model and time dimension & $37.60 \%$ & $0.00 \%$ & $12.80 \%$ & $12.80 \%$ & $36.90 \%$ & 3.11 \\
\hline $\begin{array}{l}\text { 3D architectural and structural model and facilities } \\
\text { management }\end{array}$ & $23.40 \%$ & $28.40 \%$ & $18.40 \%$ & $0.00 \%$ & $29.80 \%$ & 2.84 \\
\hline $3 \mathrm{D}$ architectural and structural model and cost dimension & $25.50 \%$ & $24.80 \%$ & $8.50 \%$ & $23.40 \%$ & $17.70 \%$ & 2.83 \\
\hline Standard 4D BIM (standard 3D BIM and time dimension) & $33.30 \%$ & $0.00 \%$ & $42.60 \%$ & $9.20 \%$ & $14.90 \%$ & 2.72 \\
\hline 3D architectural model and cost dimension & $58.90 \%$ & $0.00 \%$ & $13.50 \%$ & $9.90 \%$ & $17.70 \%$ & 2.28 \\
\hline 3D structural model and time dimension & $44.00 \%$ & $0.00 \%$ & $36.90 \%$ & $9.20 \%$ & $9.90 \%$ & 2.25 \\
\hline $\begin{array}{l}\text { 3D electrical and mechanical model and facilities } \\
\text { management }\end{array}$ & $54.60 \%$ & $27.70 \%$ & $12.80 \%$ & $0.70 \%$ & $4.30 \%$ & 1.72 \\
\hline 3D structural model and cost dimension & $48.90 \%$ & $46.80 \%$ & $4.30 \%$ & $0.00 \%$ & $0.00 \%$ & 1.55 \\
\hline $\begin{array}{l}\text { 3D architectural model and facilities management } \\
\text { information }\end{array}$ & $72.70 \%$ & $22.30 \%$ & $0.00 \%$ & $4.30 \%$ & $0.70 \%$ & 1.38 \\
\hline 3D electrical and mechanical model and time dimension & $78.40 \%$ & $8.50 \%$ & $13.10 \%$ & $0.00 \%$ & $0.00 \%$ & 1.35 \\
\hline 3D electrical and mechanical model and cost dimension & $79.40 \%$ & $7.10 \%$ & $12.80 \%$ & $0.70 \%$ & $0.00 \%$ & 1.35 \\
\hline 3D structural model and facilities management information & $70.90 \%$ & $24.10 \%$ & $5.00 \%$ & $0.00 \%$ & $0.00 \%$ & 1.34 \\
\hline
\end{tabular}

\subsection{Forms of 5D BIM being generated in the study area} Using the same Likert scale, different forms of 5D BIM were identified and used to examine the level of development of 5D BIM by the construction professionals in the study area. The result from Table 5 revealed that $60.3 \%$ of the respondents indicated very low generation of standard 5D BIM. Similarly, the usage of other forms of $5 \mathrm{D}$ BIM is very low with $29.1 \%$ indicating very low level of generation of 3D architectural-structural-time and cost dimension model, and $46.8 \%$ indicating very low level of generation of 3D architectural-electricalmechanical-time and cost model. None of the variants of 5D BIM have high level of generation. The variants of 5D BIM with low level of generation (mean score between 2.00-2.99) were Standard 5D BIM (standard 4D and cost dimension), 3D architectural, structural, time and cost dimension, 3D architectural, electrical, mechanical, time and cost dimension, 3D architectural, time and cost dimension, and 3D architectural, structural, electrical, mechanical, facilities management and cost dimension 
Table 5: Level of generating 5D BIM and its Variants among Construction Professional

\begin{tabular}{|c|c|c|c|c|c|c|}
\hline 5D BIM and its variants & $\begin{array}{l}\text { Very } \\
\text { low }\end{array}$ & Low & Average & High & $\begin{array}{l}\text { Very } \\
\text { high }\end{array}$ & $\begin{array}{l}\text { Mean } \\
\text { Score }\end{array}$ \\
\hline 3D architectural, time and cost dimension & $46.50 \%$ & $0.40 \%$ & $5.70 \%$ & $4.30 \%$ & $43.30 \%$ & 2.98 \\
\hline 3D architectural, structural, time and cost dimension & $29.10 \%$ & $9.20 \%$ & $25.50 \%$ & $28.40 \%$ & $4.30 \%$ & 2.59 \\
\hline $\begin{array}{l}\text { 3D architectural, electrical, mechanical, time and cost } \\
\text { dimension }\end{array}$ & $46.80 \%$ & $19.90 \%$ & $5.00 \%$ & $24.10 \%$ & $8.50 \%$ & 2.4 \\
\hline $\begin{array}{l}\text { 3D architectural, structural, electrical, mechanical, facilities } \\
\text { management and cost dimension }\end{array}$ & $9.90 \%$ & $59.60 \%$ & $29.10 \%$ & $0.00 \%$ & $4.30 \%$ & 2.38 \\
\hline Standard 5D BIM (standard 4D and cost dimension) & $39.70 \%$ & $27.70 \%$ & $9.20 \%$ & $19.10 \%$ & $4.30 \%$ & 2.21 \\
\hline 3D structural, electrical, mechanical, time and cost dimension & $42.60 \%$ & $45.40 \%$ & $3.50 \%$ & $5.70 \%$ & $8.50 \%$ & 1.95 \\
\hline $\begin{array}{l}\text { 3D architectural, structural, electrical, mechanical and time } \\
\text { and facilities management dimension }\end{array}$ & $60.30 \%$ & $7.80 \%$ & $17.00 \%$ & $14.90 \%$ & $0.00 \%$ & 1.87 \\
\hline 3D architectural, facilities management and time dimension & $61.00 \%$ & $15.60 \%$ & $9.90 \%$ & $5.00 \%$ & $8.50 \%$ & 1.84 \\
\hline 3D architectural, facilities management and cost dimension & $54.00 \%$ & $26.20 \%$ & $5.00 \%$ & $9.90 \%$ & $4.30 \%$ & 1.83 \\
\hline $\begin{array}{l}\text { 3D structural, electrical, mechanical, time and facilities } \\
\text { management }\end{array}$ & $51.80 \%$ & $.00 \%$ & $00 \%$ & $\%$ & $30 \%$ & 1.61 \\
\hline 3D structural, facilities management and cost dimension & $68.10 \%$ & $19.10 \%$ & $4.30 \%$ & $4.30 \%$ & $4.30 \%$ & 1.57 \\
\hline 3D structural, facilities management and time dimension & $71.60 \%$ & $24.10 \%$ & $0.00 \%$ & $0.00 \%$ & $4.30 \%$ & 1.41 \\
\hline $\begin{array}{l}\text { 3D electrical, mechanical, facilities management and time } \\
\text { dimension }\end{array}$ & $71.60 \%$ & $\%$ & $00 \%$ & $4.30 \%$ & $0.00 \%$ & 1.37 \\
\hline 3D structural, time and cost dimension & $77.70 \%$ & $21.60 \%$ & $4.30 \%$ & $0.00 \%$ & $0.00 \%$ & 1.34 \\
\hline $\begin{array}{l}\text { 3D electrical, mechanical, facilities management and cost } \\
\text { dimension }\end{array}$ & $71.60 \%$ & $27.70 \%$ & $0.70 \%$ & $0.00 \%$ & $0.00 \%$ & 1.29 \\
\hline $\begin{array}{l}\text { 3D electrical and mechanical model and time and cost } \\
\text { dimension }\end{array}$ & $74.50 \%$ & $25.50 \%$ & $0.00 \%$ & $0.00 \%$ & $0.00 \%$ & 1.26 \\
\hline $\begin{array}{l}\text { 3D structural, electrical, mechanical, facilities management } \\
\text { and cost dimension }\end{array}$ & $78.40 \%$ & $21.60 \%$ & $0.00 \%$ & $0.00 \%$ & $0.00 \%$ & 1.22 \\
\hline
\end{tabular}

\subsection{Forms of 6D BIM being generated in the study area} The current level of details in BIM is 6D comprising of Standard 5D BIM and facilities management information. However, based on the identified possible numerals and implementation strategies that could be adopted by various construction professionals, it is possible to have other forms of 6D BIM. These forms of 6D BIM were identified and presented to the respondents to rate the level of using them. The level of generation of 6D BIM and its variants among construction professionals is as explained in Table 6. In the Table, $36.9 \%$ and $37.6 \%$ of the respondents indicated that their level of generating Standard 6D BIM (Standard 5D BIM and facilities management information) were very low and low respectively. Also, as explained in Table 6, only Standard 6D BIM (Standard 5D BIM and facilities management information) had low level of usage with a mean score of 2.06 .

Table 6: Level of generating 6D BIM and its Variants among Construction Professionals

\begin{tabular}{|c|c|c|c|c|c|c|}
\hline 6D B & $\begin{array}{l}\text { Very } \\
\text { low }\end{array}$ & Low & Average & High & $\begin{array}{l}\text { Very } \\
\text { high }\end{array}$ & $\begin{array}{l}\text { Mean } \\
\text { Score }\end{array}$ \\
\hline $\begin{array}{l}\text { andard 6D BIM (Standard 5D BIM and facilities } \\
\text { anagement information) }\end{array}$ & $36.90 \%$ & $37.60 \%$ & $12.80 \%$ & $.50 \%$ & $4.30 \%$ & 2.06 \\
\hline $\begin{array}{l}\text { Standard 6D BIM (Standard 5D BIM and facilities } \\
\text { management information) }\end{array}$ & $36.90 \%$ & $37.60 \%$ & $280 \%$ & $50 \%$ & $4.30 \%$ & 2.06 \\
\hline $\begin{array}{l}\text { 3D architectural-electrical-mechanical-facilities management } \\
\text { and time dimension }\end{array}$ & $49.60 \%$ & $24.80 \%$ & $17.00 \%$ & $8.50 \%$ & $0.00 \%$ & 1.84 \\
\hline $\begin{array}{l}\text { lectrical-mechanical-facilities management } \\
\text { on }\end{array}$ & $49.60 \%$ & $\%$ & $17.00 \%$ & $\%$ & $00 \%$ & 1.84 \\
\hline $\begin{array}{l}\text { 3D architectural-structural-facilities management and time } \\
\text { dimension }\end{array}$ & $46.00 \%$ & $\%$ & 121 & $\%$ & $.00 \%$ & 1.74 \\
\hline $\begin{array}{l}\text { 3D architectural-structural-facilities management and time } \\
\text { dimension }\end{array}$ & $46.00 \%$ & $36.90 \%$ & $12.10 \%$ & $4.30 \%$ & $0.00 \%$ & 1.74 \\
\hline $\begin{array}{l}\text { 3D structural-electrical-mechanical-facilities management } \\
\text { and time dimension }\end{array}$ & 7 & 70 & 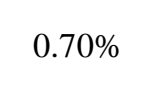 & 6 & $\%$ & 1.51 \\
\hline $\begin{array}{l}\text { 3D structural-electrical-mechanical-facilities management } \\
\text { and time dimension }\end{array}$ & $70.90 \%$ & $19.90 \%$ & $0.70 \%$ & $4.30 \%$ & $4.30 \%$ & 1.51 \\
\hline
\end{tabular}




$\begin{aligned} & \text { 3D electrical-mechanical-facilities management-time and cost } \\ & \text { dimension }\end{aligned}$
$\begin{aligned} & \text { 3D electrical-mechanical-facilities management-time and cost } \\ & \text { dimension }\end{aligned}$

\subsection{Difference in the levels of generating federated building information models among the surveyed construction professionals}

It was assumed that the construction professionals might not be developing federated building information models at the same level and level of details. To establish this supposition, a test of difference was conducted on the responses of the surveyed construction professionals and trend line was plotted to show the pattern of level of details of federated building information models being generated by the surveyed construction professionals. Fisher Exact test was conducted to examine the difference in the levels of generating federated building information models among construction professionals (Table 7). Comparing the differences in the mean rank for the professional groups, the significant value $(p=0.001)$ was less than the alpha threshold value $(p<0.05)$. Table 7 also reveals that architect, structural/civil engineers and builders were ahead of other professionals in the generation of federated building information models.

Table 7: Fisher Exact Test to examine the difference in the levels of generating federated building information models by construction professionals.

\begin{tabular}{lcccc}
\hline Construction Professionals & Number of respondents & Mean Score & Rank & Significant value \\
\hline Architect & 78 & 0.39 & 1 & \\
Builder & 59 & 0.32 & 3 & \\
Building service Engineers & 51 & 0.28 & 4 & 0.001 \\
Facilities Manager & 24 & 0.20 & 6 & \\
Quantity surveyor & 24 & 0.23 & 5 & \\
Structural/Civil Engineer & 46 & 0.34 & 2 \\
Total & 282 & & & \\
\hline
\end{tabular}

Figure 3 shows the trend line of details of building information models being developed by the surveyed construction professionals. It can be deduced from the figure that, 2D, 3D and 4D BIM were the commonly generated building information models. Using the trend line to predict the likely advancement in the levels of development of building information models in the construction industry. The level of development of building information models which started with 2D BIM and 3D BIM (3D architectural model), would advance thus: 3D BIM (architectural + structural), 3D BIM (architectural + electrical and mechanical model), 3D (structural model), 3D BIM (3D structural + electrical and mechanical model), Standard 3D BIM (3D architectural + structural + electrical and mechanical), 4D BIM (3D architectural + time dimension), Standard 4D BIM (3D architectural + structural + electrical and mechanical + time dimension), 4D BIM (3D structural model + time dimension), 4D BIM (3D structural model+ cost dimension), 5D BIM (3D architectural + structural + time + cost model), 5D BIM (3D structural + facilities management + cost model), 5D BIM (3D structural + time + facilities management model), Standard 6D BIM (3D architectural + structural + electrical and mechanical + time + cost + facilities management model), 6D BIM (3D structural + electrical and mechanical + time + cost + facilities management model), 6D BIM (3D electrical and mechanical + time + cost + facilities management model), 6D BIM (3D architectural + electrical and mechanical + time + cost + facilities management), 6D BIM (3D architectural + structural + time + cost + facilities management model. 
6D BIM (3D architectural + structural + time + cost + . .

6D BIM (3D architectural + electrical and mechanical.+

6D BIM (3D electrical and mechanical + time + cost + .

6D BIM (3D structural + electrical and mechanical + time..

Standard 6D BIM (3D architectural + structural +.

5D BIM (3D structural + time + facilities management model

5D BIM (3D structural + facilities management + cost. .

5D BIM (3D architectural + time + facilities management. .

5D BIM (3D architectural + facilities management + cost. .

5D BIM (3D electrical and mechanical + time + facilities. .

5D BIM (3D electrical and mechanical + facilities. .

5D BIM (3D structural + electrical and mechanical +.

5D BIM (3D structural + electrical and mechanical+ time. .

5D BIM (3D architectural + structural + electrical and.

5D BIM (3D architectural + structural + electrical and.

5D BIM (3D electrical and technical + time + cost model)

5D BIM (3D structural + time + cost model $)$

5D BIM (3D architectural + time + cost model)

5D BIM (3D structural + electrical and mechanical + time

5D BIM (3D architectural + electrical and mechanical +

5D BIM (3D architectural + structural + time + cost model)

Standard 5D BIM (3D architectural + structural +

4D BIM (3D architectural + structural + facilities.

4D BIM (3D architectural + structural + cost model)

4D BIM (3D electrical and mechanical model + facilities.

4D BIM (3D electrical and mechanical model + cost model)

4D BIM (3D electrical and mechanical + time model)

4D BIM (3D architectural + facilities management)

4D BIM (3D architectural model+ cost dimension)

4D BIM (3D structural + facilities management)

4D BIM (3D structural model+ cost dimension)

4D BIM (3D structural model + time dimension)

Standard 4D BIM (3D architectural + structural +. .

4D BIM (3D architectural + time dimension

Standard 3D BIM (3D architectural + structural +

3D BIM (3D structural + electrical and mechanical model)

3D (structural model)

3D BIM (architectural + electrical and mechanical model)

3D BIM (architectural + structural)

3D BIM (3D architectural model)
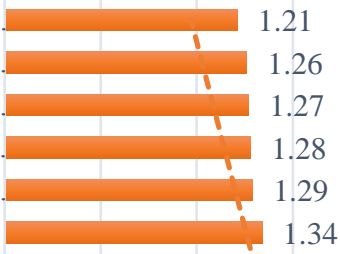

1.34
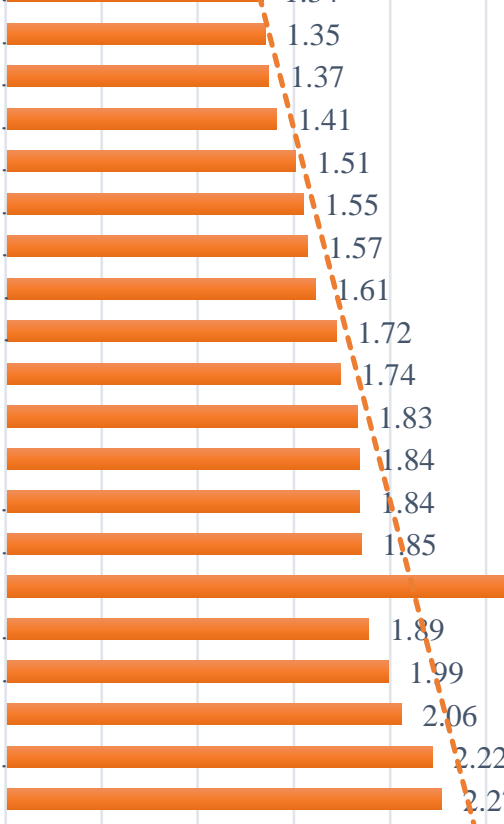

2.27
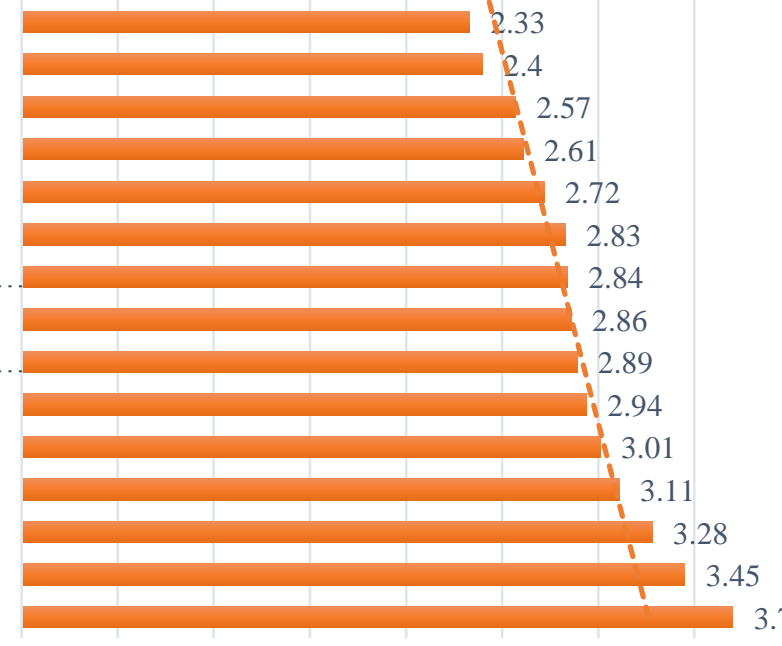

2D BIM

Figure 3: Trend line of details of building information models.

\section{Discussion}

\subsection{BIM implementation in construction projects and organizations}

Going by the information presented in Figure 1, it could be inferred that BIM process is gaining ground among professionals owing to competitiveness and availability of BIM software technologies. The results also show that professionals find BIM most useful for producing 3D models. BIM was also used to coordinate the sharing of information model among professionals. This supports and adds to the findings of Building and Construction Industry Productivity Partnership (2014) and Sawhney (2014) which found that BIM is used mostly at the visualization phase of a project and that $3 \mathrm{D}$ BIM is the most useful BIM for construction professionals.

The coordination of BIM is usually done by the Architects or Builders depending on the contractual arrangement and the criteria for appointing the project manager, in this case, BIM manager. This could explain why $18.4 \%$ of the total respondents were at visualization and coordination phase. An Architect who has adopted BIM for visualization purpose could as well be experimenting with the coordination of sharing of information models among the project team if the Architect is the appointed project manager for the project. Also, a Builder acting as the project or BIM manager on a project where Architect has adopted BIM for visualization may have to implement BIM for the 
coordination of the information models. This study found that respondents were adjusting their work process towards the BIM process. However, there is no formal adoption of BIM by the Federal Government of Nigeria or the Nigerian construction industry as a whole; therefore the adjustment of work process towards BIM adoption by the surveyed construction professionals only implies that individual organizations operating in the Nigerian construction industry were feeling the competition posed by firms that are well advanced in ICT adoption and CAD utilization for projects, and were therefore adopting BIM to be relevant and competitive in the industry.

The indication of some of the respondents that they were at all phases of BIM implementation shows that the construction professionals were lacking information on the process and framework for BIM adoption. It also suggests that construction professionals were in haste to adopt BIM for projects and work processes without having in-depth knowledge of the intricacies of BIM implementation. BIM could be adopted for projects without the project participants having implemented or adopted BIM in their respective organizations or in their work processes. It is the duty of BIM managers to coordinate BIM implementation and workflows. As pointed out by Ozorhon et al., (2010), BIM could be adopted for a project based on the project deliverables; while in organization, BIM implementation is based on the organizational objectives. For a successful implementation of BIM in a project or in an organization, the phase of implementation should be in stages and not lumped together as a one-time thing. Projects are executed in stages, and the stage where visualization is required was not the same as where coordination is required. Also, in organizations or in work processes, change comes gradually. Time is required to learn BIM processes, design BIM workflows, and integrate BIM application to work process in order to change the old method of work process.

\subsection{Level of development of $2 D$ BIM and federated building information models}

The findings in Figure 2 shows that the level of generating 2D BIM (CAD adoption) was very high among the surveyed construction professionals and this can be attributed to widespread application of software technologies and advancement in ICT in the construction industry of Lagos State. Builders, Quantity Surveyors and Facilities Managers ranked higher than the other professionals in the generation of 2D BIM. The fact that Builders use and prepare more 2D documents than every other professionals in the construction industry could be responsible for this. 2D documents such as working plan, engineering plan, construction plan, health and safety plan, and work process reports are being required to interpret and construct projects by Builders. The reason for high usage of 2D BIM software technologies such as Masterbill, QS Plus and MS Excel to develop 2D BIM for projects by Quantity Surveyors and Facilities Managers could be attributable to the unavailability of cloud-based cost analysis software technologies and digital cost information in Nigeria. However, 2D software technologies only present building information in 2D and are not so effective for developing federated building information models. This finding is consistent with other studies from Hamil (2013) and Oladapo (2006), which showed that the construction industry has fully adopted $\mathrm{CAD}$ and that the use of CAD and software technologies for design, drawing, measurement, estimating and preparation of Bill of Quantities is common among construction professionals in Nigeria.

Findings on the forms of 3D BIM being generated by the surveyed construction professionals revealed that $3 \mathrm{D}$ architectural model, 3D architectural and structural model, and 3D architectural and building services model were the most developed variants of 3D BIM. High generation of these forms of 3D BIM suggests that the construction professionals were advancing on the usage of BIM, as 3D BIM depicts the point of departure from CAD to BIM. It also means that architects and builders have ample knowledge of structural design, thereby employing CAD software technologies to analyse and develop 3D structural model. The development of 3D structural and building services model by some architects and builders implies that they have ample knowledge of structural and building services design aided by the availability of building services software technologies. The low level of generating standard 3D BIM among the respondents shows that BIM usage is a new trend among construction professionals in Nigeria and that the construction professionals lack the understanding of the appropriate level of details at which building information models should be developed.

Among the likely variants of 4D BIM, only 3D architectural model + time dimension had an appreciable level of generation by the respondents. This shows that construction professionals were adding time dimensions to $3 \mathrm{D}$ architectural model to generate a form of 4D BIM more than other forms of 4D BIM. It could be that Builders were able to add time dimension to various forms of 3D models on account of availability of software technologies such as MS Project and Autodesk Naviswork. Autodesk Naviswork and Dinamo allow Builders to develop federated building information model and simulate construction timeline by adding time schedule model from MS Project or Primavera to the federated model. A standard 3D BIM is an example of federated building information model. This study found the level of integrating standard 3D BIM with time dimension or time schedule model to be low among the respondents and this could be as a result of paucity of information on methods of developing federated building information models.

Findings on the forms of 5D BIM being generated by the respondents indicate low level of development of 5D BIM and its variants in the study area. This is an evidence of non-appreciation of BIM processes by the Quantity Surveyors whose responsibility it is to provide cost information model for extending the level of details of standard 4D BIM to the fifth dimension. If 3D BIM portrays the point of departure from CAD to BIM; then standard 3D BIM represents integration, collaboration and point of departure from fragmentation and traditional work processes in the construction industry. There are BIM software technologies that support automatic quantification and 3D taking-off; thereby enabling the development of federated building information models 
such as 5D BIM. In order to facilitate the transformation of the Nigerian construction industry, the Quantity Surveyors must switch from traditional method of quantification to automatic quantification. This finding is consistent with low adoption of BIM by the quantity surveyors and with the study by RICS (2011), which found that quantity surveyors still use traditional quantification rather than adopting automatic quantification provided by BIM.

None of the variants of 6D BIM were found to have average level of generation. This shows that facilities management is not well developed yet in Nigeria and the profession is not witnessing intense competition as being witnessed by the established professions in the construction industry. In addition, the findings explain the reasons why Facilities Managers ranked lowest among the surveyed construction professionals in the generation of federated building information models. Nevertheless, early adoption of BIM would transform the facilities management in its cradle of emergence in the Nigerian construction industry. This finding is consistent with the study by Sawhney (2014) in India, which indicated that the Facilities Managers are not adopting BIM for facilities management operations.

The usage of BIM starts from the adoption of 3D BIM which could be generated using object-based parametric software technologies. Quantity Surveyors and Facilities Managers were the top developers of 2D BIM which could not be regarded as a proper BIM, for that reason, this study examined the difference in the levels of generating federated building information models among the construction professionals in the study area. The observed difference in the levels of federated building information models being generated among the construction professionals was statistically significant. This implies that the surveyed construction professionals were not using BIM at the same degree nor generating building information models at the same level of details. The level of generating federated building information models was statistically higher among Architects, Civil/Structural engineers and Builders. This finding shows that Architects have embraced BIM more than any other construction professionals. Similar study carried out in the United States of America by Autodesk (2011), showed that six out of ten Architects use BIM.

\subsection{Inclination in the level of development of building information models}

The pattern of developing building information models was examined and the result suggests that only $3 \mathrm{D}$ architectural and engineering models were being integrated on regular basis. Though, not always to the standard form of 3D BIM. The result also shows that time dimension was being integrated occasionally to various forms of 3D BIM to generate standard 4D BIM and its other forms. Nevertheless, other dimensions such as cost and facilities management, though they were being modelled using 2D CAD, but were not being used in BIM to generate 5D and 6D BIM on account of compatibility and interoperability issues. Interoperability of authoring software technologies is a key issue in BIM processes and this is the main reason why 2D CAD software technologies are not being regarded as BIM software technologies. Likewise, information developed using 2D CAD software technologies could not be taken as a building information model. This finding is consistent with previous studies by NBS-National BIM Report (2012) and (2013) in UK and Sawhney (2014) in India, which indicated that 2D and 3D BIM are still the most prevailing level of BIM being generated among construction professionals.

Furthermore, the trend shows that 2D, 3D and 4D BIM would be generated for a very long time. Going by the information contents of 2D, 3D and 4D BIM, it could be deduced that Builders were collaborating with either Architects or Structural engineers to develop different forms of 4D BIM or develop different forms of 4D BIM by themselves or in-house. It could also mean that professionals were experimenting with various forms of BIM at lower levels of BIM details, that is, 2D, 3D and 4D BIM, depending on the demand and size of the projects for which they were using BIM. However, in complex projects that were more demanding and large in size, and where detailed information are required, professionals were using 4D and 5D BIM. This finding is consistent with study by Laiserin (2010), which indicated that the demand and size of a project should determine the level of BIM to be adopted for projects.

\subsection{Implications of the findings of this study}

The findings of this study imply that BIM adoption and implementation framework should be developed for the Nigerian construction industry as a result of the low level of development, understanding and adoption of BIM in the construction industry and amongst construction professionals. The framework should describe the level of development of building information models appropriate for various project characteristics. Also, educational and professional institutions should strategize on how to make construction professionals to understand, adopt and implement BIM.

\section{Conclusion}

Levels of development of building information models is a function of the phase of BIM implementation and the creation of federated building information models. This paper examined the phase of BIM implementation adopted for work processes and the level of generating different forms of building information models by construction professionals in Lagos State, Nigeria. The paper establishes that BIM is used mostly at the visualization phase in project delivery for the production of 3D models. In general, 2D and 3D BIM are still the most prevailing building information models being generated. Although, 4D BIM was barely being created, but the level of details were not consistent with the standard form of adding time dimension to standard 3D BIM. The forms of 3D and 4D BIM being generated in the study area are 3D architectural model, 3D structural model only, 3D architectural and structural model, and 3D architectural and time dimension. The level of development of 5D BIM in Lagos State, Nigeria is very low because Quantity Surveyors are still using 2D CAD for quantification rather than adopting $3 \mathrm{D}$ taking-off methods. This connotes that the status of BIM adoption in 
construction industry in Lagos State, Nigeria is at the visualization phase.

Architects, Engineers and Builders in the study area are generating building information models more than the other professionals owing to the fact that they have

\section{References}

Arcadis (2015) BIM according to Acadis. Available from: www. Arcadis.nl/2015. [Accessed 19th May 2015].

Austalian institute of architects (2014) BIM in practice. Available from. [Accessed 23rd July 2017].

Autodesk (2002) Building Information Modelling. San Rafael. Autodesk Building Industry Solutions. Available from: http://www.autodesk.org/bim. [Accessed 19th May 2015].

Autodesk (2011) Realizing the benefits of BIM. San Rafael. Autodesk Building Information Modelling. Available from: http://www.autodesk.org/bim. [Accessed 19th May 2015].

Bhargav, D. (2014) A brief introduction to BIM. A presentation at Aalto University, school of engineering, 23 April, 2014.

BIM forum (2015) level of development specification for building information models: 2015. Available from. http://bimforum.org/wp-content/uploads/2013/08/2013LOD-Specification.pdf. [Accessed 23rd July 2017].

BIM Guide (2013) First steps to BIM competence: a guide for specialist contractors. SEC Group, National Specialist Contractors Council BIM working Group.

BIM Planning Guide for Facilities Managers (2012) A building smart alliance projects, version 2.0., Computer Integrated Construction, University Park, PA, The Pennsylvania State University.

Bolpagni, M. (2013) The implementation of BIM within the public procurement: a model-based approach for the Construction Industry. Espoo 2013, VTT Technology 130, Finland.

British Standard Institute (2013) Specification for information management for the capital/delivery phase of construction projects using Building Information Modelling, UK. BSI Standards Limited.

Building and Construction Industry Productivity Partnership (2014) BIM in New Zealand - an industrywide view 2014. Available from: www.eboss.co.nz. [Accessed 19th May 2015].

Building Information Council (2014) Dutch BIM Level. Arcadis, the Information Technology Group, 4 April, 2014.

Computer Integrated Construction Research Program (2012) BIM planning guide for facility owners. Version 1.0. University Park, P.A, the Pennsylvania State University.

Construction Product Association (2013) BIM for the terrified: a guide for manufacturer. NBS, June 2013, London, Construction Products Association.

Dare-Abel, O. A., Igwe, J. M., and Charles, K. A. (2014) Proficiency and capacity building of human capital in architectural firms in Nigeria. International Conference on Science, Technology, Education, Arts, Management \& Social Sciences, iSTEAMS Research Nexus Conferene, Afe Babalola University, Ado-Ekiti, Nigeria, May, 2014. knowledge of each other's profession and form the core of design and construction team members. The findings of this paper are limited to the construction industry in Lagos state, Nigeria.

Dim, N. U., Ezeabasili, A. C. C., and Okoro, B. U. (2015) Managing the change process associated with BIM implementation by the public and private investors in the Nigerian Building Industry. Donnish Journal of Engineering and Manufacturing Technology, 2(1):001006.

Eadie, R., Odeyinka, H., Browne, M., McKeown, C., and Yohanis, M. (2014) BIM adoption: an analysis of the barriers to implementation. Journal of Engineering and Architecture, 2(1): 77-101.

Ede, A. N. (2014) BIM: case study of a duplex building project in Nigeria. International Journal of IT, Engineering \& Applied Sciences Research, 3(4).

Engineering News Record (2014) Show me the money: 5D-cost estimating tools taking off. STV Magazine, ENR-Records.

Glenn, D. S. (2013) Determining Sample Size. University of Florida. IFAS Extension. Available from. http://www.edis.ifas.ufl.edu. [Accessed 19th May 2015].

Hamil, S. (2013) Level 2 BIM. National Building Specifications (NBS) international BIM report, RIBA Enterprises Limited.

Ian, H. \& Bob, B. (2010) BIM 2years later-huge potentials, some success and several limitations. Newforma, International Alliance for Interoperability.

Jung, W. and Lee, G. (2015) The status of BIM adoption on six continents. World academy of science, engineering and technology. International journal of civil, environmental, structural, construction and architectural engineering, 9(4).

Kossinets, G. and Watts, D. J. (2006) Empirical Analysis of an Evolving Social Network. Science, 311(5757):88-90.

Laiserin, J. (2010) Designer's BIM: Vectorworks $\square$ Architect Keeps design at the centre of BIM process. The Laiserin LetterTM, 26 (Special edition) March 2010.

Lu, W. and Li, H. (2011) Building Information Modelling and changing construction practices. Automation in Construction. 20 (2011): 99-100.

McCarthy, C., Killworth, P.D., Bernard, H.R., Jonhsen, E., and Shelley, G.A. (2001) Comparing Two Methods for Estimating Network Size. Human Organization, 2001 (60):28-39.

National BIM Report (2013) National Building Specifications (NBS) BIM report. RIBA Enterprises Limited.

National BIM Report (2014) National Building Specifications (NBS) BIM report. RIBA Enterprises Limited.

National Building Specification BIM Report (2014) National Building Specifications (NBS) BIM survey, RIBA Enterprises Limited.

National Institute of Standards and Technology (2015) Kruskal Wallis. US Commerce Department. Available from: http//: www.itl.nist.gov. [Accessed 19th May 2015]. 
Newton, K. and Chileshe, N. (2014) Awareness, usage and benefits of Building Information Modelling (BIM) adoption - the case of the South Australian construction organisations In: Smith, S.D (eds.) Procs 28th Annual ARCOM Conference, 3-5 September 2012, Edinburgh, UK, Association of Researchers in Construction Management, 3-12.

Oakley, P. (2014) BIM-are you BIM Level 2 ready? BIM, BRE Associate Director.

Oladapo, A. A. (2006) The impact of ICT on professional practice in the Nigerian Construction Industry. The Electronic Journal on Information Systems in Developing Countries, 24(2): 1-19.

Onungwa, I. O. and Uduma-Olugu, N. (2017) BIM and collaboration in the Nigerian construction industry. Journal of construction business and management. University of Cape Town. 1 (2): 1-10.

Ozorhon, B., Abbott, C., Aouad, G. and Powell, J. (2010) Innovation in Construction A Project Life Cycle Approach. CIB Joint International Symposium, 903-912.

Panuwatwanich, k., Wong, M. L., Doh, J., Stewart, R. A. and McCarthy, T. J. (2013) Integrating BIM into engineering education: An exploratory study of industry perceptions using social network data. Proceedings of the 2013 AAEE conference, Gold Coast, Queensland, Australia.

Porwal, A. \& Hewage, K.N. (2013) BIM Partnering framework for Public Construction Projects. Information Technology in Construction 31 (2013) 204-214.

Practical BIM (2012) BIM-management, implementation, coordination and evaluation. In M. K. Karen (eds.).The USC BIM symposium, school of Architecture, University of Southern California, Los Angeles, California.

RICS (2011) BIM Report BCIS. Available from: www.RICS_BIM_survey.co.uk. [Accessed 19th May 2015]

Royal Architectural Institute of Canada (2007) BIM. Canada, RAIC practice builder.

Royal Institute of British Architects (2012) BIM overlay to the RIBA outline plan of work, London, RIBA publishing.
Sabol, L. (2008) BIM and facility management, world work place, International facility management association (IFMA).

Sawhney, A. (2014) State of BIM adoption and outlook in India. Royal Institution of Chartered Surveyors (RICS) Research, School of Built Environment, Amity University, India.

Scott, D., Chong, M.K.W., and Li, H. (2005) Webbased construction information management systems.

The Australian journal of construction economic and building, 3(1): 43-52.

Sebastian, R (2010) BIM. D2.4 of EU KP7, Trans- IND project.

Shelden, D. (2009) Information Modelling as a Paradigm Shift. Architectural Design, 79(2):80-83.

Simpson, M. (2013) A definition of BIM. The structural engineer, 9(7): 16-20.

Smith M. (2013) What is BIM? NBS, National BIM library, RIBA enterprises.

Succar, B. (2009) BIM framework: a research and delivery foundation for industry stakeholders. Automation in construction, 18 (3): 357-375.

UK BIM alliance (2016) BIM in the UK: Past, present and future. Available from. http://www.ukbimalliance.org/media/1050/ukbima_bimr eview_past_present_future_20161019-1.pdf. [Accessed 23rd July 2017].

UK Natioanl BIM Report (2017) S pecification Report 2017. Avaialble from. http://www. thenbs.com/specificationreport2017. [Accessed 23rd July 2017].

Velasco, A. U. (2013) Assessment of 4D BIM applications for project management functions. Master thesis, University of Cantabria.

VicoSoftware (2015) Grayscale BIM. Trimble, VicoSoftware Integrating Construction.

Weisstein, E.W. (1999) Fisher's Exact Test. Mathword. Available from. www.http://mathword.wolfram.com/fishersexacttest.htm 1. [Accessed 19th May 2015] 